\title{
Recurrent Lip and Oral Cavity Squamous Cell Carcinoma
}

National Cancer Institute

\section{Source}

National Cancer Institute. Recurrent Lip and Oral Cavity Squamous Cell Carcinoma. NCI

Thesaurus. Code C115442.

The reemergence of lip and oral cavity squamous cell carcinoma after a period of remission. 